\title{
PEMETAAN BAHAYA LONGSOR DENGAN METODE ANALITYCAL HIERARCHY PROCESS DI GUNUNG ARJUNO WELIRANG, JAWA TIMUR
}

\author{
Arief Rachmansyah $^{1^{*}}$, Ardian Baroto $^{2}$, Ika Meisy Putri Rahmawati $^{3}$ \\ ${ }^{1}$ Dosen, Jurusan Teknik Sipil, Fakultas Teknik, Universitas Brawijaya \\ ${ }^{2}$ Geologist, Alumni Program Sarjana Teknik Geologi UGM \\ ${ }^{3}$ Geotechniker, Alumni Program Magister Teknik Sipil Universitas Brawijaya \\ *Korespondensi: $\underline{\text { ariefftub@ub.ac.id }}$
}

\begin{abstract}
Indonesia has enormous geothermal potential because most of Indonesia's territory is located in an active volcano route. One of the challenges in developing geothermal energy is that its location is located on the slopes of a Quaternary Volcanoes which is suceptible to landslides. The purpose of the research that has been carried out is to determine the distribution of landslide-hazard areas on the western slopes of the ArjunoWelerang Volcano. The analysis was performed using the Analytical Hierarchy Process method based on morphological, geological and structural geological parameters. Geomorphological mapping was carried out by contour map analysis, then classified based on morphometry and morphogenesis. Geological mapping uses the principle of volcanostratigraphy, while mapping of geological structures is done by analyzing contour maps made by Digital Evalation Model and field checking. The high and very high landslide hazard zones are scattered along the fault zone, while the very high landslide hazard areas are located in the ancient crater valleys.
\end{abstract}

Keywords : landslide hazard, volcanostratigraphyi, Analitycal Hierarchy Process

\section{PENDAHULUAN}

Seiring dengan peningkatan jumlah penduduk dan kesejahteraannya, kebutuhan energi juga akan terus meningkat. Seiring dengan tuntutan lingkungan hidup yang semakin meningkat, sumber energi yang dimanfaatkan bergeser dari energi dengan emisi tinggi ke energi emisi rendah, bahkan energi yang terbarukan. Panas bumi merupakan salah satu energi dengan emisi rendah dan dapat diperharui.

Indonesia memiliki potensi panas bumi yang sangat besar, karena sebagian besar wilayah Indonesia terletak di jalur gunungapi api aktif. Salah satu tantangan dalam pengembangan energi panas bumi adalah lokasinya terletak di bagian lereng gunungapi yang rawan longsor, karena batuannya belum terlitifikasi sempurna. Salah satu wilayah kerja panas bumi di Provinsi Jawa Timur berada di sekitar Gunungapi Arjuno-Welirang.
Sebelum dilakukan pengembangan potensi panasbumi perlu dilakukan pemetaan daerah rawan bencana, yang bermanfaat bagi keselamatan pekerja dan kesinambungan infrastruktur eksplorasi maupun eksploitasi. Berdasarkan laporan yang dikeluarkan oleh Badan Nasional Penanggulangan Bencana tahun 2019 menunjukan, bahwa selama 10 tahun terakhir kejadian bencana banjir, longsor dan banjir bandang menunjukkan peningkatan kejadian maupun korban [1].

Tujuan dari penelitian ini adalah untuk mengetahui sebaran daerah rawan longsor di lereng bagian barat Gunungapi ArjunoWelirang dengan menggunakan metode analisis dalam Sistem Informasi Geografis (SIG) dan metode Analytical Hierarchy Proccess (AHP).

Longsoran adalah suatu proses perpindahan massa tanah dan / atau massa batuan dengan arah miring, sehingga terjadi pemisahan dari massa yang mantap. Faktor yang 
mempengaruhi longsoran sangat banyak, tetapi yang utama adalah gravitasi dan rembesan air tanah. Dalam beberapa kasus longsoran menggambarkan bagaimana kondisi geologi dapat sangat mempengaruhi proses longsoran. [2]. Longsoran dapat terjadi dalam berbagai bentuk, dan cara memprakirakannya sangat beragam, kecepatan gerakan, material yang bergerak, dan faktor lainnya yang mempengaruhi secara langsung terhadap keruntuhan lereng [3].

\section{METODE PENELITIAN}

Penelitian dilakukan di lereng bagian barat dari Kompleks Gunungapi Arjuno Welirang (Gambar 1). Secara administrasi lokasi kegiatan termasuk dalam wilayah Kabupaten Pasuruan, Kabupaten Mojokerto dan Kota Batu Provinsi Jawa Timur.

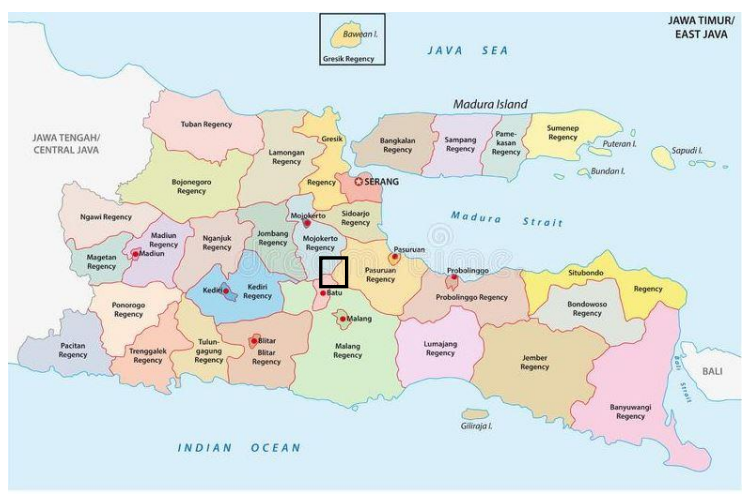

Gambar 1. Lokasi Pemetaan Bahaya Longsor di Kompleks Gunungapi Arjuno Welirang

Pelaksanaan penelitian dibagi dalam beberapa tahapan, yakni:

1. Pembuatan peta tematik daerah penelitian, khusunya yang berguna untuk pembuatan peta bahaya longsor, yakni peta morfologi dan kemiringan lereng, peta geologi atau geologi gunungapi, dan peta struktur geologi. Analisis peta topografi digital menjadi peta tematik dilakukan dengan bantuan perangkat lunak GIS, serta mengacu pada pustaka yang sesuai. Selain itu juga dilakukan pengecekan di lapangan terhdap peta tematik yang dibuat.

2. Analisis zona bahaya longsor dilakukan dengan metode Analitycal Hierarchy Process (AHP). Metode ini dilakukan cara memberikan bobot setiap parameter, sesuai dengan tingkat pengaruhnya terhadap kejadian bencana tersebut, sehingga dihasilkan daerah bahaya rendah hingga sangat tinggi.

\subsection{Sistem Informasi Geografis (SIG)}

Sistem Informasi Geografis adalah suatu komponen yang terdiri dari perangkat keras, perangkat lunak, data geografis dan sumber daya manusia yang bekerja bersama secara efektif untuk memasukkan, menyimpan, memperbaiki, memperbaharui, mengelola, menginterpretasikan, menganalisa, dan menampilkan data dalam suatu informasi berbasis geografis. SIG terdiri atas empat subsistem, yaitu: data masukan (input), data storage and retrieval, data manipulation and analysis, dan data keluaran (reporting) [4].

1. Data masukan (Input) : berfungsi untuk mengumpulkan dan menyiapkan data spasial dan data atribut serta mengkonversi atau mentransformasi format data aslinya ke dalam format data SIG.

2. Data keluaran (Reporting) : berfungsi untuk menampilkan atau menyajikan keluaran seluruh basis data baik dalam bentuk softcopy maupun hardcopy, seperti : grafik, tabel, peta, dan lainlain.

3. Data Storage and Retrieval : berfungsi mengorganisasikan data spasial dan data atribut dalam basis data sehinngga mudah dipanggil, di update, dan di edit.

4. Data Analysis and Manipulation : berfungsi untuk menentukan informasi-informasi yang dapat dihasilkan oleh SIG serta melakukan manipulasi dan pemodelan data untul menghasilkan informasi yang diharapkan.

\subsection{Analytical Hierarchy Process (AHP)}

Metode Analytical Hierarchy Process (AHP) dikembangkan pertama kali oleh Thomas L pada tahun 1970-an ketika di Wartson School. Metode AHP merupakan salah satu metode yang dapat digunakan dalam sistem pengambilan keputusan dengan memperhatikan faktor-faktor persepsi, preferensi, pengalaman, dan intuisi [5]. AHP menggabungkan penilaianpenilaian dan nilai-nilai pribadi ke dalam satu cara yang logis. AHP merupakan suatu model pendukung keputusan yang menguraikan masalah multi faktor atau multi kriteria yang kompleks menjadi satu hierarki [6].

Secara grafis, persoalan keputusan AHP dapat dikonstruksikan sebagai diagram 
bertingkat, yang dimulai dengan goal atau sasaran, lalu kriteria level pertama, subkriteria, dan akhirnya alternatif. AHP memungkinkan pengguna untuk memberikan nilai bobot relatif dari suatu kriteria majemuk (atau alternatif majemuk terhadap suatu kriteria) secara intuitif, yaitudengan melakukan perbandingan berpasangan (Pairwise Comparisons).

\section{HASIL DAN PEMBAHASAN}

\subsection{Geologi Regional}

Kompleks Gunungapi Arjuno Welirang terletak pada zona Gunungapi Kuarter. Di daerah ini manivestasi panasbumi ditunjukkan oleh mata air panas di Cangar dan Songgoriti Batu, serta Padusan Mojokerto.

Basement pada area Gunung ArjunoWelirang diperkirakan batuan sedimen yang masuk Zona Kendeng yang melampar di bagian Jawa Timur. Di daerah Bangil Pasuruan beberapa formasi dari Zona Kendeng yang dijumpai dibawah batuan Gunungapi Arjuno Welirang antara lain Formasi Pucangan dan Formasi Kabuh. Di daerah Jombang (Barat laut dari Gunungapi Arjuno-Welirang) kelompok batuan Gunungapi Arjuno-Welirang yang terbentuk pada Kuarter Bawah menumpang di atas Formasi Jombang. Formasi ini disetarakan dengan Formasi Pucangan. Formasi Pucangan tersusun oleh material gunungapi yang diendapkan di laut, sedangkan Formasi Kabuh merupakan sedimen dengan material vulkanik yang diendapkan pada lingkungan fluviatil [7].

Di bagian barat daerah penelitian terdapat gunungapi berumur Awal Pleistosen Tengah yang menghasilkan Satuan Batuan Gunungapi Anjasmoro Tua (Qpat). Pada Pleistosen Tengah, bagian tengah Gunung Anjasmoro Tua tidak aktif lagi dan mengalami fase denudasi yang cukup kuat, sehingga terjadi bentuk morfologi gunungapi stadium tua. Pada Pleistosen Tengah terjadi kegiatan gunungapi yang membentuk Satuan Gunungapi Kuarter
Bawah (Qp). Satuan ini menimpa satuan Gunungapi Anjasmoro Tua dan tertutup oleh Satuan Gunungapi Arjuno-Welirang.

\subsection{Morfologi dan Kemiringan Lereng}

Analisis geomorfologi dapat digunakan sebagai data awal untuk penentuan daerah bahaya kebumian dan prakiraan dampak lingkungan. Analisis geomorfologi menggunakan peta kontur dengan skala 1:25.000 dan citra satelit Digital Elevation Model (DEM).

Penentuan satuan geomorfologi mengacu pada menurut yang mencakup aspek morfometri (bentuk /bentang alam) dan morfogenesa (proses geologi). Morfologi utama di daerah penelitian yang teridentifikasi berupa punggungan gunungapi, perbukitan gunungapi, lereng, dan kerucut gunungapi, bukit intrusi, dan kipas aliran piroklastik [8].

Kemringan lereng Kemiringan Lereng curam - sangat curam umum dijumpai di lembah yang merupakan hasil endapan Gunungapi muda. Lembah yang ditemui umumnya memiliki tinggi lebih dari $40 \mathrm{~m}$ dengan lereng yang sangat curam sehingga sangat berbahaya jika dikombinasikan dengan kondisi batuan pada tepi lembah yang umumnya lapuk menengah hingga tinggi. Selain itu jika dikombinasikan dengan kondisi struktur geologi seperti sesar turun maupun geser akan menjadi zona yang amat rawan untuk mengalami pergerakan tanah (Gambar 2).

Alasan dipilihnya aspek ini menjadi aspek dengan pembobotan tertinggi kedua adalah kemiringan Lereng di sekitar Puncak Welirang memiliki kelas yang curam sampai sangat curam terutama pada lembah-lembah. Berdasarkan hasil tinjauan lapangan lapangan, lembahlembah tersebut relatif stabil, meskipun tersusun oleh batuan dengan tingkat pelapukan menengah sampai sangat tinggi. Di sepanjang lembah jarang ditemukan mahkota longsoran. 


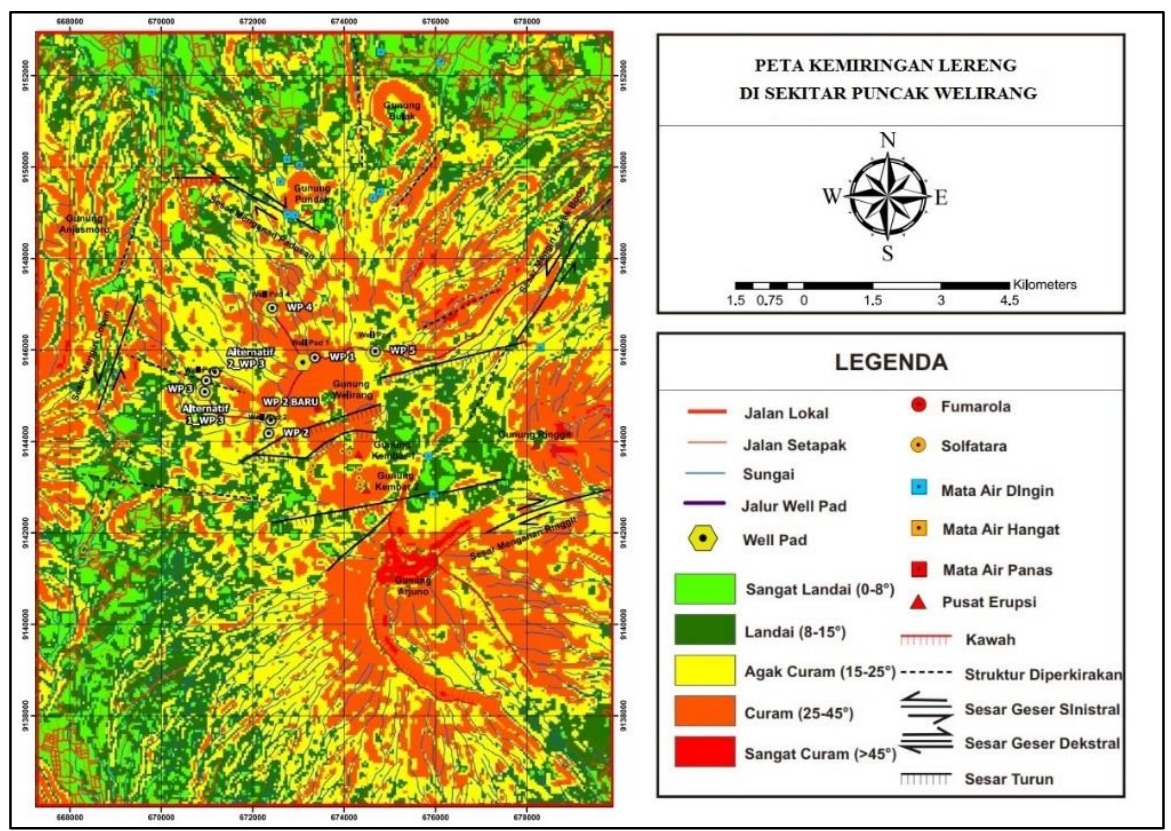

Gambar 2. Peta kemiringan lereng di lereng sebelah barat Gunungapi Arjuno - Welirang

Berdasarkan kemiringan lerengnya daerah penelitian dapat dikelompokkan menjadi 5 kelas yaitu: Sangat Landai dengan nilai 1, Landai dengan nilai 2, Sedang dengan nilai 3, Curam dengan nilai 4, dan Sangat Curam dengan nilai 5. Bobot untuk parameter Kemiringan Lereng bernilai 0.3 dari 1 .

\subsection{Litologi}

Dalam mengggolongkan satuan batuan di daerah yang didominasi batuan hasil aktivitas gunungapi baik langsung maupun tidak langsung umumnya digunakan prinsip vulkanostratigrafi. Prinsip ini merupakan penggolongan batuan gunungapi secara bersistem berdasarkan sumber, deskripsi dan genesa. Tatanan satuan stratigrafi gunung api didasarkan pada sumber, jenis batuan dan urutan kejadian [9].

Berdasarkan prinsip vulkanostratigrafi batuan yang dijumpai di lereng bagian barat Gunungapi Arjuno Welirang tersusun atas Aliran Lava Welirang (Wl) dengan nilai 1, Aliran Piroklastik Welirang (Wap) dengan nilai 3, Aliran Lava Kembar (Kl) dengan nilai 1, Aliran Piroklastik Kembar (Kap), Aliran Lava Bekal (Bl) dengan nilai 1, Aliran Lava Pundak (Pl) dengan nilai 1, Aliran Lava Bulak (Bul) dengan nilai 1, Aliran Lava Lali Jiwo (Ll) dengan nilai 1, Aliran Piroklastik Ringgit (Rap) dengan nilai 3, Aliran Lava Arjuno (Al) dengan nilai 1, Aliran Piroklastik Arjuno (Aap) dengan nilai 3, Aliran Lava Anjasmoro (Anl) dengan nilai 1, Aliran Piroklastik Anjasmoro (Anp) dan Guguran Vulkanik Arjuno (Agv) dengan nilai 5 (Gambar 3).

Secara ringkas satuan aliran lava memiliki nilai terendah 1 dikarenakan lava yang dijumpai merupakan batuan yang bersifat kompak dan memiliki tingkat pelapukan paling rendah dari satuan lain, sedangkan pada aliran piroklastik dijumpai batuan yang sifatnya belum kompak dan memiliki tingkat pelapukan yang relatif cukup tinggi, dan pada guguran vulkanik sifatnya belum kompak dan memiliki tingkat pelapukan paling tinggi dari satuan lain.

Satuan Aliran Lava yang ditemukan menunjukkan tipe batuan andesit yang bersifat kompak serta umumnya memiliki tingkat pelapukan yang relatif rendah sehingga batuan cukup stabil apabila tidak terpotong oleh struktur geologi yang dominan. Pada Satuan Aliran Piroklastik menunjukkan sifat yang kurang kompak dengan ukuran butir relatif kasar - sedang dan tingkat pelapukan yang relatif tinggi. Hasil pengamatan lapangan satuan ini relatif stabil terhadap pergerakan tanah akibat lereng yang curam akan tetapi faktor struktur geologi yang memotong satuan ini perlu menjadi perhatian mengingat sifatnya yang kurang kompak dan dominasi tingkat pelapukan batuan yang tinggi. 


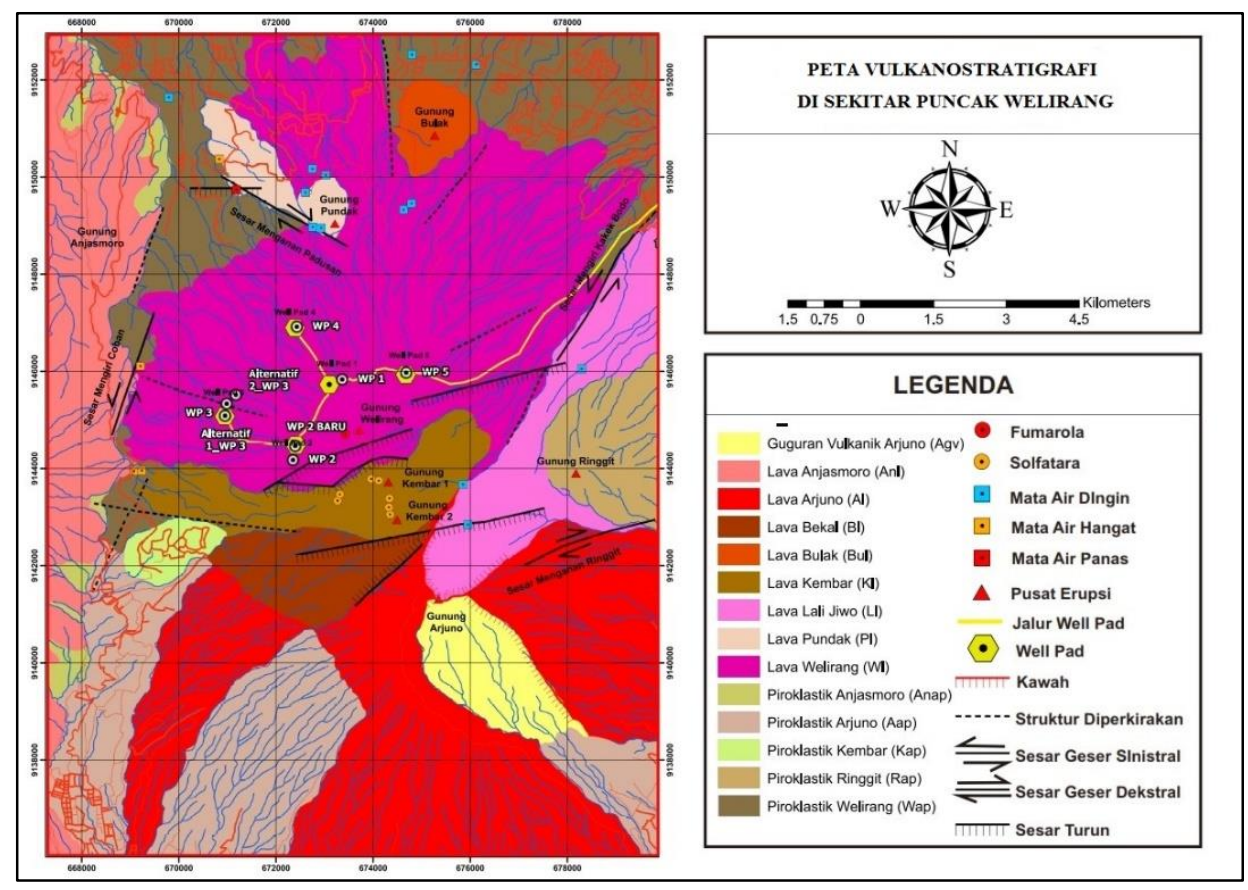

Gambar 3. Peta Geologi di lereng bagian Barat Gunung Arjuno Welirang dengan penyatuan berdasarkan volcanostratigrafi

Alasan aspek ini menjadi aspek dengan pembobotan terendah di daerah penelitian, karena satuan batuan yang ditemukan memiliki tingkat pelapukan dan tingkat kompaksi yang bervariasi. Akan tetapi kondisi di lapangan menunjukkan stabilitas tinggi, jarang ditemukan mahkota longsoran di semua jenis batuan, dengan tingkat kompaksi, maupun tingkat pelapukannya yang berbeda-beda. Akan tetapi perlu menjadi perhatian pada Satuan Aliran Piroklastik dan Guguran Vulkanik jika bertemu dengan struktur geologi dan kelerengan yang curam.

\subsection{Struktur Geologi}

Struktur Geologi yang dijumpai adalah Sesar Geser Dekstral, Sesar Geser Sinistral, Sesar Turun, dan Sesar-sesar diperkirakan [10]. Pada Gambar 4 merupakan sebaran Struktur Geologi di lereng barat Gunung Arjuno Welirang. Aspek Struktur Geologi untuk analisis bahaya longsor di lereng sebelah Barat Gunung Arjuno-Welirang merupakan aspek yang memiliki pembobotan paling besar.

Pada Gambar 5-A ditemukan struktur geologi berupa sesar turun pada Aliran Lava Welirang dengan kedudukan $\mathrm{N} 86^{\circ} \mathrm{E} / 22^{\circ}$ dengan kondisi batuan lapuk rendah pada koordinat $\mathrm{x} y$. Kemudian pada Gambar 5-B ditemukan sesar turun pada Aliran Piroklastik Welirang dengan kedudukan $\mathrm{N} 80^{\circ} \mathrm{E} / 63^{\circ}$ dengan kondisi batuan lapuk sedang pada koordinat $\mathrm{x} y$. Dengan gambaran kondisi struktur geologi tersebut sangat tidak direkomendasikan untuk pembangunan trase jalan dan well-pad karena secara studi tektonik sesar tersebut dimungkinkan masih aktif karena memotong batuan hasil Gunungapi berumur Kuarter karena Arjuno-Welirang termasuk ke dalam kompleks gunungapi berumur Kuarter yang terbentuk akibat adanya subduksi Lempeng Indo-Australia terhadap Eurasia.

Pembobotan struktur geologi di daerah penelitian terbagi menjadi 3 kelas berdasarkan kenampakan pada DEM dan hasil pengamatan lapangan yaitu : Zona Struktural Tegas diberi bobot 5, Zona Struktural Diperkirakan diberi bobot 3, dan Zona yang tidak terdapat patahan diberi bobot 1 . 


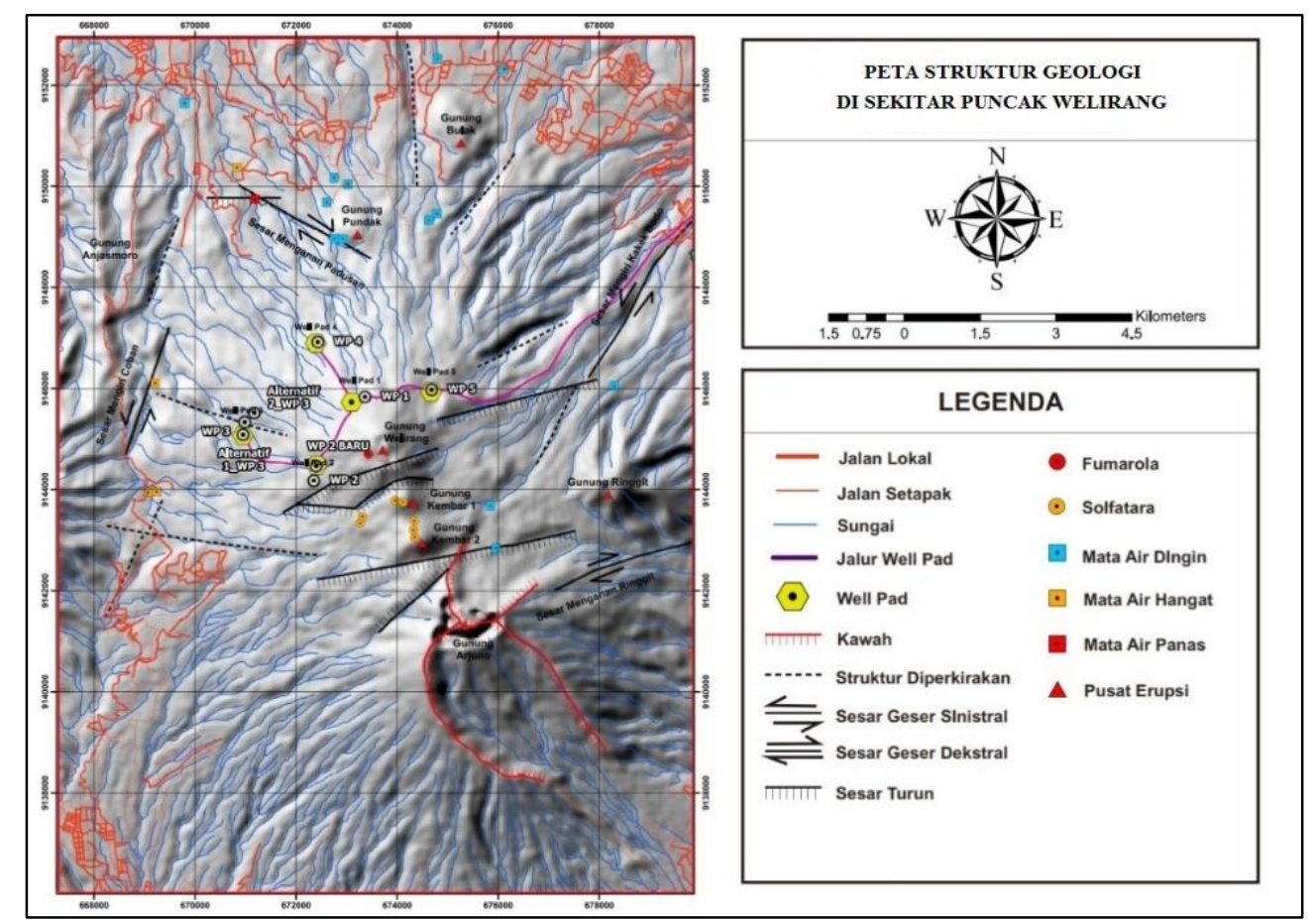

Gambar 4. Peta struktur geologi di lereng bagian barat Gunungapi Arjuno - Welirang
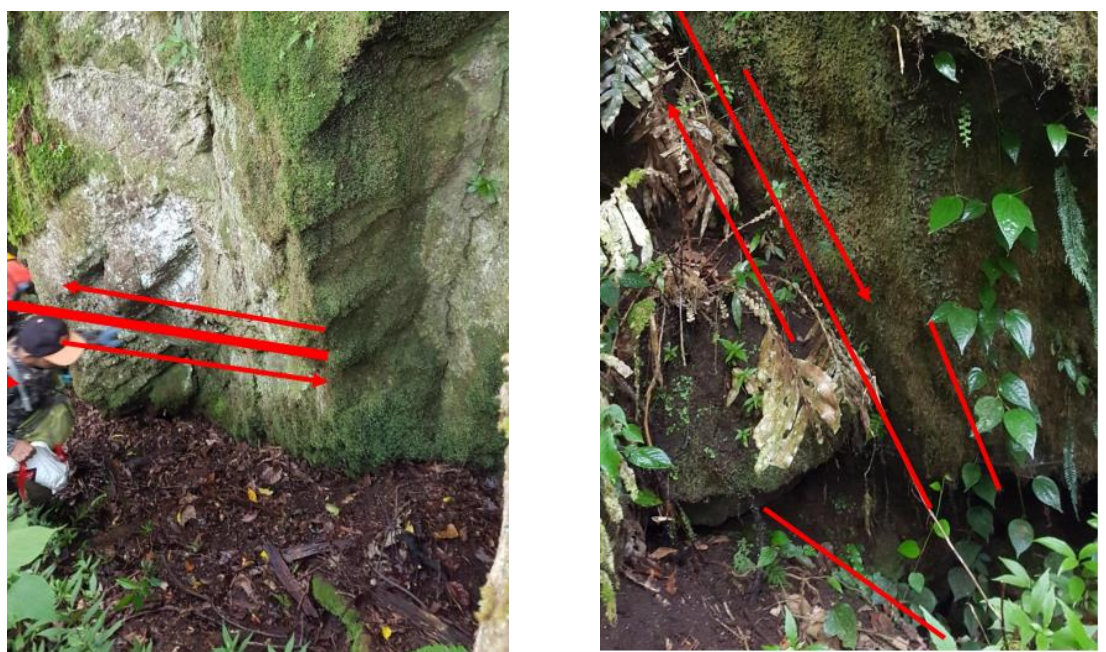

Gambar 5. Pada A (kiri) ditemukan sesar turun pada aliran Lava Welirang, pada B (kanan) ditemukan sesar turun pada Aliran Piroklastik Welirang

Alasan dipilihnya aspek ini menjadi aspek dengan pembobotan tertinggi dari ketiga parameter adalah:

1. Daerah penelitian merupakan kompleks gunungapi berumur Kuater yang masih aktif terbentuk disebabkan oleh subduksi dari Lempeng Indo-Australia terhadap Lempeng Eurasia sejak Eosen Tengah hingga masa kini [10].

2. Di lereng bagian barat Gunungapi Arjuno -Welirang merekam deformasi
Kenozoikum berarah dominan NE- SW dan NE-SW, dan kemungkinan hari ini masih aktif dengan pergerakan Arah E-W yang lebih tampak dominan di area utara kemungkinan juga ada di selatan, tetapi banyak terkubur oleh produk vulkanik modern. Implikasi dari tatanan tektonik tersebut adalah aktivasi struktur geologi yang terjadi aliran fluida termal.

3. Pembangunan infrastruktur pemanfaatan panas bumi membutuhkan keselamatan 
kerja dan kesinambungan prasarana kerja, sedangkan keberadaan struktur geologi sering menjadi pemicu keruntuhan lereng .

\subsection{Daerah Bahaya Longsor}

Untuk meranking tingkat bahaya longsor di daerah penelitian digunakan metode AHP (Analytical Hierarchy Process) dengan tiga (3) parameter utama yaitu kemiringan lereng, jenis batuan / litologi, dan struktur geologi. Masingmasing parameter memiliki pembobotan yang berbeda sesuai dengan skala prioritas yang disusun serta perhitungan dalam metode AHP.

Zonasi Bencana Geologi Longsor dilakukan dengan melakukan pembobotan pada masing - masing aspek yang digunakan dengan menggunakan metode AHP. Aspek Struktur Geologi memiliki bobot 0.6 dari 1, Aspek Kemiringan Lereng memiliki bobot 0.30 dari 1.00, sedangkan Aspek Batuan memiliki bobot 0.1 dari 1.0. Rincian perhitungannya adalah sebagaimana Tabel 1.

Selanjutnya dilakukan perhitungan pairwise comparison dengan memberikan perbandingan nilai antar parameter dapat dilihat pada Tabel 1, Struktur Geologi bernilai 2x dari Kemiringan Lereng, sedangkan terhadap Jenis Batuan bernilai 5x. Kemudian Aspek Kemiringan secara otomatis bernilai 0.5 dari Struktur Geologi dan bernilai 3x dari Jenis Batuan, Sedangkan untuk Aspek Batuan secara otomatis bernilai 0.2 dari Aspek Struktur Geologi dan bernilai 0.3 dari Aspek Kemiringan Lereng. Hasil perhitungan ini menghasilkan $\mathrm{O}$, $\mathrm{P}$, dan $\mathrm{Q}$ yang digunakan untuk menghitungkan normalisasi tiap parameter yang akan menjadi bobot dari masing - masing parameter nantinya (Tabel 2).
Tabel 1. Perhitungan Pairwise Comparison dari ketiga aspek

\begin{tabular}{|c|c|c|c|}
\hline$(\mathrm{x})$ & $\begin{array}{c}\text { Struktur } \\
\text { Geologi }\end{array}$ & $\begin{array}{c}\text { Kemiringan } \\
\text { Lereng }\end{array}$ & $\begin{array}{c}\text { Jenis } \\
\text { Batuan }\end{array}$ \\
\hline $\begin{array}{c}\text { Kemiringan } \\
\text { Lereng }\end{array}$ & 0.5000 & 1.0000 & 3.0000 \\
\hline Jenis Batuan & 0.2000 & 0.3333 & 1.0000 \\
\hline Struktur Geologi & 1.0000 & 2.0000 & 5.0000 \\
\hline Total & $\mathbf{1 . 7 0 0 0}$ & $\mathbf{3 . 3 3 3 3}$ & $\mathbf{9 . 0 0 0 0}$ \\
\hline & $\mathrm{O}$ & $\mathrm{P}$ & $\mathrm{Q}$ \\
\hline
\end{tabular}

Pada Tabel 2 dapat dilihat dilakukan normalisasi terhadap perbandingan tiap parameter dengan jumlah total tiap kolom kemudian seluruhnya dijumlah secara horizontal dan dinormalisasi terhadap nilai total tersebut. Pada hasil akhir R, S, dan T menghasilkan bobot untuk tiap-tiap parameter diatas. Pada Tabel 3 dilakukan perhitungan konsistensi terhadap perhitungan Pairwise Comparison yang telah dilakukan dengan mengalikan $\mathrm{O}$ dengan $\mathrm{R}, \mathrm{P}$ dengan $\mathrm{S}$, dan $\mathrm{Q}$ dengan $\mathrm{T}$ yang menghasilkan amaks. Kemudian dilakukan perhitungan CI dengan mengurangi $\partial$ maks dengan jumlah data yaitu 3 dan dibagi jumlah data -1 . Setelah itu untuk mendapatkan $\mathrm{CR}$ dilakukan dengan pembagian CI dengan RI (untuk RI merupakan sebuah ketentuan sesuai dengan jumlah data). Kemudian hasil CR harus bernilai $<0.1$ sehingga dapat dikatakan konsisten.

Dari perhitungan tersebut, kemudian diimplementasi pada dengan cara overlay, sehingga dihasilkan peta bahaya longsor (Gambar 6). Tingkat bahaya longsor dibagi menjadi 5 kategori, dari potensi sangat rendah sampai sangat tinggi.

Tabel 2. Perhitungan Normalisasi dari ketiga aspek

\begin{tabular}{|c|c|c|c|c|c|c|}
\hline$(\mathbf{x})$ & $\begin{array}{c}\text { Struktur } \\
\text { Geologi }\end{array}$ & $\begin{array}{c}\text { Kemiringan } \\
\text { Lereng }\end{array}$ & $\begin{array}{c}\text { Jenis } \\
\text { Batuan }\end{array}$ & Total & $\begin{array}{c}\text { Norm. } \\
\text { Sum }\end{array}$ & \\
\hline Struktur Geologi & 0.5882 & 0.6000 & 0.5556 & 1.7438 & 0.5813 & $\mathrm{R}$ \\
\hline $\begin{array}{c}\text { Kemiringan } \\
\text { Lereng }\end{array}$ & 0.2941 & 0.3000 & 0.3333 & 0.9275 & 0.3092 & $\mathrm{~S}$ \\
\hline Jenis Batuan & 0.1176 & 0.1000 & 0.1111 & 0.3288 & 0.1096 & $\mathrm{~T}$ \\
\hline Total & $\mathbf{1 . 0 0 0 0}$ & $\mathbf{1 . 0 0 0 0}$ & $\mathbf{1 . 0 0 0 0}$ & $\mathbf{3 . 0 0 0 0}$ & $\mathbf{1 . 0 0 0 0}$ & \\
\hline
\end{tabular}


Tabel 3. Perhitungan Batas Konsistensi

\begin{tabular}{|c|c|c|c|}
\hline OxR & 0.9881 & CI & 0.0025 \\
\hline PxS & 1.0305 & RI & 0.5800 \\
\hline QxT & 0.9863 & CR & 0.00424461 \\
\hline Omaks & 3.0049 & & \\
\hline
\end{tabular}

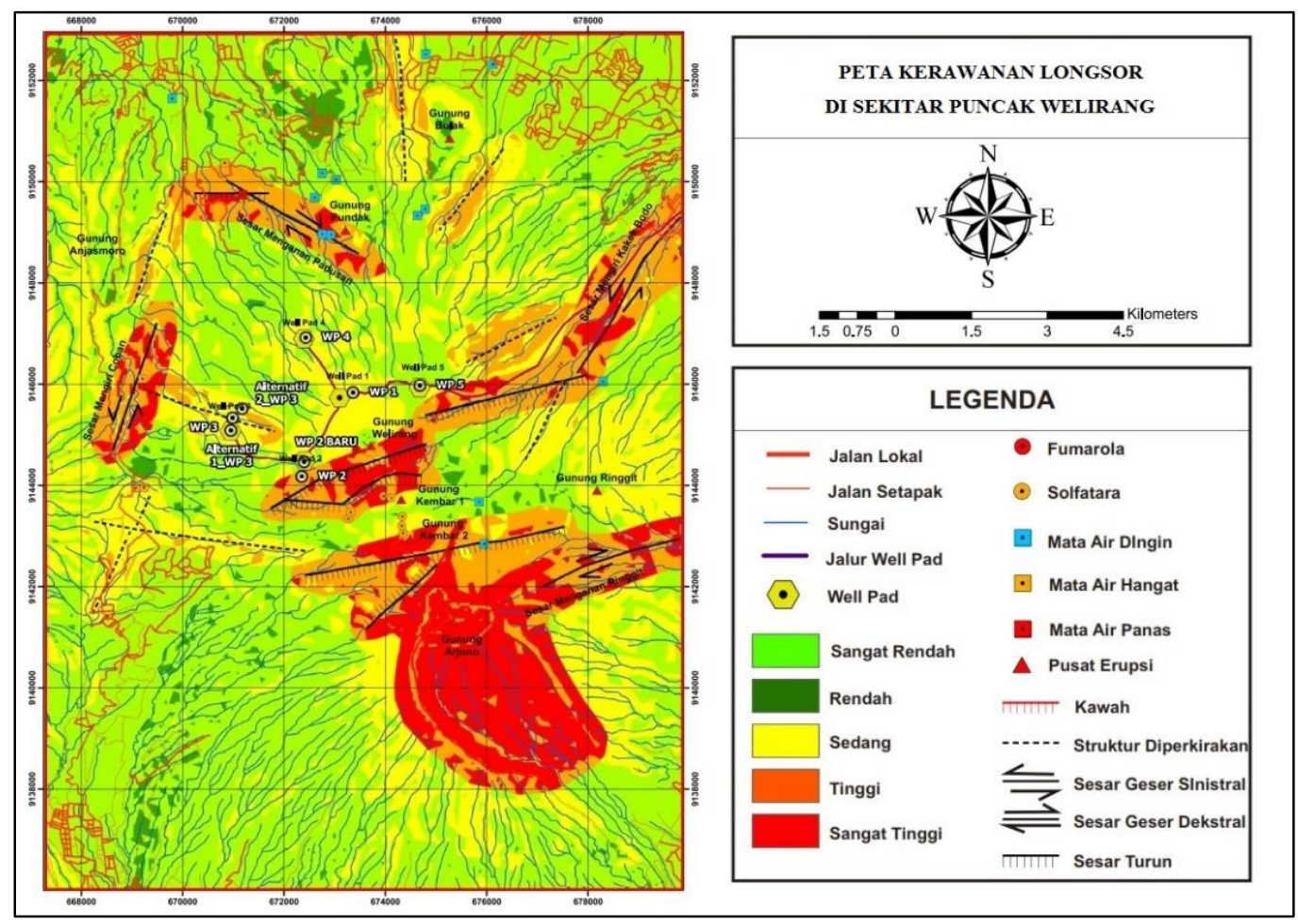

Gambar 6. Zonasi Bahaya Longsor di lereng Gunung Arjuno - Welirang bagian barat

\section{KESIMPULAN}

Dengan metode AHP daerah rawan longsor di lereng bagian barat Gunungapi Arjuno Welirang dapat digolongkan rendah sampai tinggi. Zona bahaya longsor tinggi dan sangat tinggi tersebar di sepanjang zona patahan, sedangkan di daerah bahaya longsor sangat tinggu terletak di lembah bekas kawah.

\section{UCAPAN TERIMA KASIH}

Ucapan terima kasih disampaikan sebesar-besarnya kepada PT. Geodipa Energi yang telah menyediakan data dan dana penelitian ini. Ucapan terima kasih juga diucapkan pada suadara Johnedi Situmorang dan Sulistyo Widodo yang banyak membantu dalam pelaksanaan penyelidikan lapangan.

\section{DAFTAR PUSTAKA}

[1] Badan Penanggulangan Bencana Nasional, 2019, Laporan Kejadian Bencana tahun 2019.

[2] Cheng, Y. M. And Lau, C.K., 2014. Slope Stability Analysis and Stabilization, CRC Press.

[3] Hunt, R E., 2006. Geologic Hazard, A Field Guide for Geotechnical Engineers, Taylor and Francis, New York.

[4] Carrara, A., Guzzetti F., Cardinali M. and Reichenbach P., 1999, Use of GIS Technology in the Prediction and Monitoring of Landslide Hazard, Natural Hazards 20, pp 117-135.

[5] Vaidya, O S. and Kumar, S., 2006, Analytic Hierarchy Process: An overview of applications, European Journal of Operational Research 169, pp 1-29.

[6] Hongsen Luo, Yong He, Guohui Li and Ji Li, 2016, Slope Stability Analysis of Open Pit Mine Based on AHP and Entropy Weight Method, International Journal of Security and Its Applications Vol. 10, No. 3, pp.283-294. 
[7] Santoso, S dan Suwarti, T., 1992, Peta Geologi Lembar Malang skala 1:100.000, Pusat Penelitian dan Pengembangan Geologi, Departemen Pertambangan dan Energi, Bandung.

[8] Brahmantyo, B. dan Bandono, 2006, Klasifikasi Bentuk Muka Bumi (Landform) untuk Pemetaan Geomorfologi pada Skala 1:25.000 dan Aplikasinya untuk Penataan
Ruang, Jurnal Geoaplika Volume 1, Nomor 2, hal. $071-078$.

[9] Agus Harjanto, 2011, Vulkano-stratigrafi Di Daerah Kulon Progo Dan Sekitarnya,, Daerah Istimewa Yogyakarta, Jurnal Ilmiah MTG, Vol. 4, No.2, Juli 2011.

[10] LAPI ITB, 2019, Laporan Penyelidikan Geofisika di Wilayah Kerja Panasbumi Arjuno Welirang, Bandung (Laporan untuk PT Geodipa Energi). 